\title{
PEMBERDAYAAN PEREMPUAN DALAM MEMBANGUN KEMANDIRIAN EKONOMI
}

\author{
Rizqy Aiddha Yuniawati ${ }^{1)}$ \\ 1)Program Studi S1 Akuntansi, Fakultas Ekonomi dan Bisnis, Universitas Airlangga, Banyuwangi, \\ Jawa Timur, Indonesia \\ Corresponding author : Rizqy Aiddha Yuniawati \\ E-mail : rizqy.aiddha.y@feb.unair.ac.id
}

Diterima 04 Oktober 2021, Direvisi 16 Oktober 2021, Disetujui 16 Oktober 2021

\begin{abstract}
ABSTRAK
Pengabdian masyarakat ini bertujuan untuk memberikan pengetahuan dan keterampilan para perempuan yang berusia produktif mengenai kewirausahaan serta memanfaatkan peluang bisnis di era digital dan di masa pandemi, sehingga para perempuan dapat berdaya secara ekonomi. Program pengabdian masyarakat melibatkan 132 perempuan berusia produktif dari seluruh Indonesia. Program pengabdian masyarakat ini dilakukan melalui beberapa tahap. Tahap pertama adalah memetakan usaha yang akan membantu perekonomian para perempuan. Tahap kedua adalah tahap pelaksanaan dan tahap ketiga adalah tahap evaluasi untuk memastikan para peserta dapat memiliki panduan dalam memulai atau mengembangkan usahanya. Hasil kegiatan ini menunjukkan bahwa setelah mendapatkan pengetahuan dan keterampilan sebagian besar peserta $(75 \%)$ memiliki motivasi yang tinggi untuk memulai dan mengembangkan usaha yang diukur dengan skala motivasi berwirausaha. Selain itu, semua peserta memandang bahwa kegiatan ini sangat bermanfaat karena menambah pengetahuan dan keterampilan dalam berwirausaha. Dengan demikian, diharapkan para perempuan mampu berdaya secara ekonomi baik di masa pandemi maupun pasca pandemi.
\end{abstract}

Kata kunci: era digital; kewirausahaan; pandemi; perempuan; pemberdayaan

\begin{abstract}
This community service aims to provide productive women with skills and knowledge regarding entrepreneurship and take advantage of business opportunities in the digital era and during the pandemic so that women can be economically empowered. This community service program involved 132 participants from all over Indonesia. The implementation of this community service program is carried out virtually or through webinars. The results of this activity indicate that after gaining knowledge and skills most of the participants have high motivation to start and develop businesses. In addition, all participants saw that this activity was very useful because it added knowledge and skills in entrepreneurship. Thus, it is hoped that women will be able to be economically empowered both now and in the future.
\end{abstract}

Keywords: digital era; entrepreneurship; pandemic; women; empowerment

\section{PENDAHULUAN}

Peran perempuan pada masyarakat kuno lebih ditekankan pada sektor domestik sebuah keluarga, yaitu memasak dan mengurus anak. Perempuan ibarat pemain di belakang panggung yang memiliki peran penting namun tak pernah tampil dimuka umum. Seiring perkembangan zaman dan munculnya emansispasi, membawa banyak perubahan pada peran perempuan, erat kaitannya dengan kesetaraan peran perempuan dan laki-laki dalam sebuah keluarga (Abidin, 2017). Tidak jarang perempuan bekerja untuk menghidupi keluarganya, bahkan menjadi tulang punggung sebuah keluarga.
Banyak perempuan yang menuntut ilmu setinggi-tingginya demi memperoleh pekerjaan yang menjanjikan bagi kehidupan keluarganya. Diiringi dengan ketekunan dan keuletan seorang perempuan, maka banyak pula perempuan yang menduduki peran penting dalam sebuah negara, seperti menjadi seorang lurah, camat, bupati, menteri dan bahkan presiden. Hal ini tidak menjadi masalah bagi perempuan yang memiliki kesempatan mengeyam pendidikan yang tinggi (Tasia \& Nurhasanah, 2019). Namun, perempuan yang tidak memiliki kesempatan mengeyam pendidikan tinggi tentunya akan kalah bersaing dengan perempuan lain. Kondisi ekonomi dan tingkat 
pendidikan masyarakat yang relatif rendah membutuhkan pendampingan dan penyuluhan untuk memanfaatkan potensi yang ada di desa dan lingkungannya. Kaum perempuan usia produktif merupakan salah satu potensi desa yang dapat dikembangkan dengan membekali keterampilan dan pengetahuan yang dapat dimanfaatkan sebagai penunjang perkembangan ekonomi masyarakat desa (Abidin, 2017). Perempuan yang memiliki waktu menganggur merupakan modal dan kesempatan yang dapat dimanfaatkan untuk kegiatan produktif sehingga dapat menjadi sumber pendapatan, sehingga perempuan tersebut tidak hanya menjadi ibu rumah tangga pada umumnya, namun bisa menjadi ibu rumah tangga yang berdaya secara ekonomi (Garba \& Abubakar, 2019).

Pemberdayaan bermakna pemberian daya atau penguatan kepada masyarakat (Kurniawati, 2013). Pemberdayaan memiliki tujuan untuk membantu memperoleh daya dalam mengurangi adanya hambatan sosial dan pribadi dalam mengambil suatu keputusan (Antonites \& Vuuren, 2005). Di sisi lain, pemberdayaan yang dilakukan pada seseorang atau sekelompok orang akan mampu membangkitkan kepercayaan diri untuk mencapai suatu harapan (Kim et al., 2012).

Salah satu implementasi pemberdayaan dapat dilakukan dengan kewirausahaan (Omar, 2021). Menurut Sun et al., (2020) kewirausahaan bermakna tindakan yang yang dilakukan guna pemenuhan kebutuhan hidup dengan mengunggulkan kemampuan, keahlian dan potensi yang dimilikinya. Kemampuan tersebut digunakan untuk menciptakan sesuatu yang baru dengan nilai tambah guna menghasilkan keuntungan dan kepuasan konsumen.

Usaha untuk memperkuat pengetahuan dan keterampilan kewirausahaan masyarakat dapat dilakukan dengan cara melakukan perpindahan ilmu pengetahuan dan keterampilan (transfer knowledges and lifeskills). Usaha ini dapat memberikan dampak yang besar, apalagi jika ilmu pengetahuan dan keterampilan tersebut dapat memanfaatkan sumberdaya yang ada di lingkungan masyarakat tersebut untuk diolah menjadi sesuatu yang memiliki nilai tambah (Antonites \& Vuuren, 2005).

Pengabdian masyarakat ini bertujuan untuk transfer ilmu pengetahuan dan keterampilan secara daring atau sering disebut dengan webinar. Bahasan dalam webinar program pengabdian masyarakat ini diantaranya adalah membuat peta bisnis dengan bisnis model canvas, menemukan dan menciptakan nilai tambah bisnis, menentukan target pasar yang tepat, membuat survey pasar, menciptakan bisnis yang memberikan solusi, mengembangkan saluran pemasaran, membentuk mental dan mindset sukses pengusaha perempuan, menentukkan arah dan tujuan bisnis, menciptakan identitas bisnis, membuat anggaran keuangan, menghitung harga jual yang benar dan menguntungkan serta menyusun laporan keuangan sederhana.

Untuk memanfaatkan peluang bisnis di era digital dan di masa pandemi ini salah satu bisnis yang paling menjanjikan adalah bisnis kuliner. Prospek usaha ini akan terus cemerlang mengingat kuliner atau makanan merupakan kebutuhan pokok bagi semua manusia. Salah satu bisnis bidang kuliner yang bisa dijalankan adalah bisnis katering. Usaha katering menjadi tren bisnis belakangan ini dan jumlah pengusaha katering terus meningkat sehingga persaingan di dalam bisnis katering ini cukup ketat. Usaha katering ini sangat cocok di jalankan oleh ibu rumah tangga, karena memasak merupakan kegemaran dari ibu rumah tangga. Bisnis katering juga cocok dijalankan bagi yang memiliki kegemaran terhadap makanan atau bagi yang melihat peluang yang besar di dalam bisnis katering ini. Namun, saat ini tuntutan jaminan pangan yang bergizi, aman dan bermutu terus meningkat. Keamanan pangan menjadi kunci dalam mencegah penyakit-penyakit via makanan (foodborne diseases). Konsumen menginginkan makanan yang bergizi dan aman sehingga masalah keamanan makanan menjadi sangat penting bagi industri dan bisnis makanan. Pelaku usaha makanan wajib memproduksi dan memasarkan makanan yang aman dan sesuai. Selain itu dengan semakin berkembangnya teknologi dan pemanfaatan teknologi bisnis di media online merupakan opsi yang menguntungkan bagi yang ingin membuka usaha ataupun yang mengembangkan usaha. Bisnis online memiliki lahan pasar yang cukup besar, apalagi ketika masyarakat diharuskan tetap tinggal di rumah maupun melakukan rutinitas pada masa pandemi, semakin banyak konsumen yang beralih ke e-commerce dan berbelanja ritel makanan secara daring.

Program pengabdian masyarakat ini bertujuan untuk memberikan pengetahuan dan keterampilan kepada para perempuan di usia produktif untuk dapat memanfaatkan peluang bisnis di era digital dan di masa pandemi ini, salah satunya adalah dengan 
bisnis catering sehat, sebab di masa pandemi dan di masa pasca pandemi hampir semua orang ingin mengonsumsi makanan dengan gizi dan kebersihan yang terjaga.

\section{METODE PELAKSANAAN}

Program pengabdian masyarakat ini dirancang untuk memberikan ilmu pengetahuan dan keterampilan para perempuan yang berusia produktif yaitu perempuan dengan usia 17 - 40 tahun, mengenai kewirausahaan serta memanfaatkan peluang bisnis di era digital dan di masa pandemi, sehingga para perempuan dapat membuka atau mengembangkan usaha yang dirintis secara mudah tanpa adanya interaksi secara langsung antara penjual dan pembeli. Dengan demikian, maka para perempuan dapat berdaya secara ekonomi.

Pelaksanaan program pengabdian masyarakat ini dilakukan secara daring atau melalui webinar. Topik webinar program pengabdian masyarakat ini adalah "Pemberdayaan Perempuan Dalam Membangun Kemandirian Ekonomi”. Adapun tahapan dalam kegiatan webinar ini adalah sebagai berikut:

1. Tahap Persiapan

a. Melakukan survei terhadap jenis peluang usaha yang berada di lingkungan sekitar.

b. Melakukan survei secara daring kepada mitra yang sudah dipilih.

c. Menentukan narasumber yang tepat untuk memberikan materi webinar.

d. Melakukan perencanaan untuk webinar.

2. Tahap Pelaksanaan

a. Program pengabdian masyarakat ini dilaksanakan 18 Juli 2020 sampai dengan 10 Oktober 2020. Webinar dilaksanakan pada tanggal 26 September 2020. Webinar ini diikuti oleh 132 peserta, terdiri dari peserta yang akan memulai usaha atau yang sedang ingin mengembangkan usahanya. Dalam webinar ini yang menjadi narasumber adalah Ibu Tri Siwi Agustina selaku pakar kewirausahaan menjelaskan mengenai Business Model Canvas yaitu pedoman penentuan arah usaha yang harus dilakukan supaya peserta dapat menghemat sumberdaya baik berupa modal, waktu, dan tenaga untuk mendapatkan hasil yang maksimal dalam bisnis. Materi yang kedua dipaparkan oleh lbu Indiarti selaku owner indies' kitchen, yaitu mengenai cara membentuk mental, mindset sukses pengusaha perempuan, dan tips serta trik untuk memulai berbisnis.

3. Tahap Tindak Lanjut

Setelah serangkaian program pengabdian masyarakat ini dilaksanakan, evaluasi perlu dilakukan dalam hal kualitas materi webinar yang dipaparkan serta memastikan para peserta dapat memiliki panduan dalam memulai atau mengembangkan usahanya.

\section{HASIL DAN PEMBAHASAN}

Program pengabdian masyarakat dengan tema "Pemberdayaan Perempuan Dalam Membangun Kemandirian Ekonomi” di inisiasi oleh Rizqy Aiddha Yuniawati. Narasumber webinar program pengabdian masyarakat ini adalah Tri Siwi Agustina selaku pakar kewirausahaan dan Indiarti selaku pemilik usaha yang kian meroket di masa pandemi ini.

Tahapan pertama dalam program pengabdian masyarakat ini adalah tahap persiapan. Tahap persiapan ini terdiri dari tiga langkah, yaitu survei lingkungan, penentuan narasumber yang tepat, dan perencanaan program pengabdian masyarakat. Langkah pertama dari tahap ini adalah survei kondisi lingkungan saat ini yang di latar belakangi oleh semakin merajalelanya Covid 19, di dorong pula oleh kemajuan teknologi, sehingga hampir semua orang memanfaatkan media online dalam bertransaksi. Objek transaksi tersebut beragam bentuknya guna memenuhi kebutuhan rumah tangga dengan mengurangi intensitas bertemunya penjual dan pembeli sebagai salah satu upaya juga dalam pemutusan mata rantai Covid 19. Langkah kedua adalah penetapan narasumber yang tepat sehingga dapat membangkitkan semangat dan motivasi para perempuan untuk dapat berdaya secara ekonomi di masa pandemi ini dengan memanfaatkan media online. Maka narasumber pertama yang dipilih adalah seorang akademisi yang memiliki kepakaran dalam hal kewirausahaan, yaitu Tri Siwi Agustina. Narasumber kedua adalah pelaku bisnis yang kian melejit dengan memanfaatkan media online, yaitu Indiarti. Langkah selanjutnya dalam tahap perencanaan yaitu dengan mempertimbangkan berbagai hal, diantaranya adalah waktu, media yang akan digunakan, dan poin materi-materi yang perlu dipaparkan oleh para narasumber.

Tahap kedua dari program pengabdian masyarakat ini adalah tahap pelaksanaan. Program pengabdian masyarakat ini dilaksanakan pada tanggal 26 September 2020. Webinar ini diikuti oleh 132 peserta, terdiri dari peserta yang akan memulai usaha atau yang mengembangkan usaha. Narasumber pertama yaitu Tri Siwi Agustina selaku pakar 
kewirausahaan memaparkan cara membuat peta bisnis dengan bisnis model canvas, menemukan dan menciptakan nilai tambah bisnis, menentukan target pasar yang tepat, membuat survey pasar, menciptakan bisnis yang memberikan solusi dan mengembangkan saluran pemasaran. Sedangkan narasumber kedua yaitu Indiarti selaku pelaku usaha memberi pemaparan tentang cara membentuk mental dan mindset sukses pengusaha perempuan, menentukkan arah dan tujuan bisnis, menciptakan identitas bisnis, membuat anggaran keuangan, menghitung harga jual yang menguntungkan dan menyusun laporan keuangan sederhana.

Business model canvas yaitu pedoman penentuan arah usaha yang harus dilakukan supaya peserta dapat menghemat sumberdaya baik berupa modal, waktu, dan tenaga untuk mendapatkan hasil yang maksimal dalam bisnis (Herawati et al., 2019). Business model canvas (BMC) memiliki sembilan elemen penting dalam membantu mengidentifikasi model bisnis dan membanru mengidentifikasi elemen-elemen yang memerlukan perbaikan untuk kelangsungan usaha, sehingga dapat menciptakan sesuatu yang baru dan memiliki nilai tambah. Business model canvas ini dapat digunakan sebagai alat untuk memberikan rancangan model bisnis yang baru (Hartatik \& Baroto, 2017).

Materi selanjutnya yang dipaparkan Tri Siwi Agustina adalah menentukan target pasar yang tepat. Sasaran pelanggan atau target pasar merupakan konsumen yang dinilai potensial membeli atau menggunakan produk/jasa. Dengan menentukan sasaran pelanggan yang tepat dapat menghindari terjadinya sepi pembeli. Menentukan target pasar yang tepat dapat menggunakan beberapa kriteria, diantaranya adalah daya beli; gaya hidup; minat/hobby; usia; tempat tinggal; pekerjaan; dan gender. Selain itu sebagai pelaku usaha perlu mencari tahu pengalaman target pasar terhadap produk/jasa yang telah dikonsumsinya. Dengan demikian, pelaku usaha mendapat informasi mengenai kelemahan atau keunggulan atas produk/jasa yang diproduksinya. Untuk dapat mencapai profitabilitas yang tinggi, hal yang perlu dilakukan oleh para pelaku usaha adalah membuat saluran pemasaran yang tepat dengan target pasar sesuai dengan survey yang telah dilakukan.

Materi narasumber yang kedua dimulai dengan memberikan motivasi terhadap para peserta, yaitu cara untuk membentuk mental dan mindset di tengah perekonomian dunia yang makin terpuruk akibat Covid 19. Materi selanjutnya yaitu mengenai cara menentukan tujuan dan arah bisnis. Hal tersebut sangat diperlukan agar pelaku usaha konsisten atau tidak terombang-ambing oleh pasang surutnya bisnis saat ini, sebab untuk memulai bisnis pun memerlukan modal yang tidak sedikit. Dengan kemantapan hati pelaku usaha dalam menjalankan bisnisnya, maka identitas bisnis akan terbentuk dengan baik.

Program pengabdian masyarakat ini tidak hanya memberikan ilmu pengetahuan mengenai kewirausahaan, namun juga memberikan keterampilan dalam hal merencanakan anggaran bisnis, menentukan harga jual yang menguntungkan serta cara untuk menyusun laporan keuangan sederhana. Hal tersebut dipaparkan juga oleh Indiarti selaku pemilik usaha katering. Keterampilan tersebut menggunakan contoh usaha katering yang dimilikinya. Namun, keterampilan yang telah dipaparkan tersebut tidak menutup kemungkinan untuk diaplikasikan pada banyak lini bisnis yang akan dijalankan oleh para peserta.

Tahap ketiga dari program pengabdian masyarakat ini evaluasi. Setelah serangkaian program pengabdian masyarakat ini dilaksanakan, evaluasi perlu dilakukan dalam hal kualitas materi webinar yang dipaparkan serta memastikan para peserta dapat memiliki panduan dalam memulai atau mengembangkan

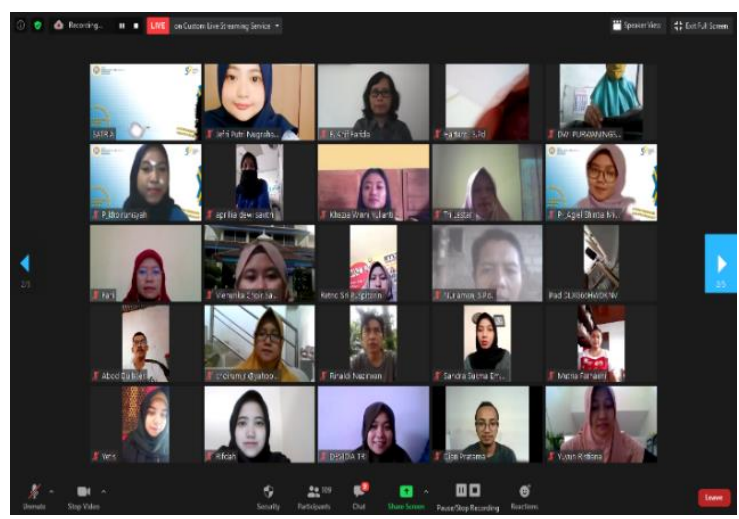

Gambar 1. Pengabdian Masyarakat PPDMKE

\section{SIMPULAN DAN SARAN}

Dari program pengabdian masyarakat yang telah dilakukan maka dapat disimpulkan bahwa pengetahuan dan keterampilan mengenai cara membuat peta bisnis dengan bisnis model canvas, menciptakan nilai tambah bisnis, menentukan target pasar yang tepat, membuat survey pasar, menciptakan bisnis yang memberikan solusi, mengembangkan saluran pemasaran, membentuk mental dan mindset sukses, menentukkan arah dan tujuan bisnis, menciptakan identitas bisnis, membuat anggaran keuangan, menghitung harga jual yang menguntungkan serta menyusun laporan 
keuangan sederhana sangat penting dalam menjalankan bisnis. Pelaksanaan pengabdian masyarakat berjalan lancar tanpa hambatan hingga akhir acara, para peserta memiliki antusiasme dan semangat yang tinggi terlihat dari para peserta yang aktif dalam tanya jawab. Semua peserta memandang bahwa kegiatan ini sangat memberikan dampak yang dapat diterima masyarakat sesuai dengan tujuan kegiatan yaitu Pengabdian Masyarakat.

Saran praktis yang dapat disampaikan sehubungan dengan program pengabdian masyarakat dengan tema "Pemberdayaan Perempuan Dalam Membangun Kemandirian Ekonomi" yaitu selalu memberikan pengetahuan dan keterampilan yang berkesinambungan kedepannya, agar para peserta dapat meningkatkan pengetahuan dan keterampilan dalam berwirausaha.

\section{DAFTAR RUJUKAN}

Abidin, Z. (2017). Kesetaraan Gender dan Emansipasi Perempuan dalam Pendidikan Islam. Tarbawiyah Jurnal Ilmiah Pendidikan, 12(01), 1-17.

Antonites, A. J., \& Vuuren, J. J. Van. (2005). Inducing Entrepreneurial Creativity, Innovation and Opportunity - Finding Skills. 8(3), 255-271.

Garba, M. M., \& Abubakar, S. L. (2019). The Influence of Entrepreneurial Learning Environment and Intrinsic Learners' Need on Entrepreneurship Education. Open Journal of Business and Management, 07(03), 1244-1261. https://doi.org/10.4236/ojbm.2019.73087

Hartatik, ., \& Baroto, T. (2017). Strategi Pengembangan Bisnis Dengan Metode Business Model Canvas. Jurnal Teknik Industri, 18(2), 113. https://doi.org/10.22219/jtiumm.vol18.no2 .113-120

Herawati, N., Lindriati, T., \& Suryaningrat, I. B. (2019). Penerapan Bisnis Model Kanvas Dalam Penentuan Rencana Manajemen Usaha Kedelai Edamame Goreng. Jurnal Agroteknologi, $\quad 13(01), \quad 42$. https://doi.org/10.19184/j-agt.v13i01.8554

Kim, B. C., Lee, G., Murrmann, S. K., \& George, T. R. (2012). Motivational effects of empowerment on employees' organizational commitment: A mediating role of management trustworthiness. Cornell Hospitality Quarterly, 53(1), 10-19. https://doi.org/10.1177/19389655114265 61

Kurniawati, D. (2013). Pemberdayaan Masyarakat Di Bidang Usaha Ekonomi (Studi Pada Badan Pemberdayaan Masyarakat Kota Mojokerto). Jurnal

\section{Administrasi Publik}

Universitas Brawijaya, 1(4), 9-14.

Omar, K. M. (2021). Measuring the Entrepreneurship Characteristics and Its Impact on Entrepreneurial Intentions. Open Journal of Business and Management, 09(02), 672-687. https://doi.org/10.4236/ojbm.2021.92035

Sun, D., Chen, H., Wu, P., \& Yang, D. (2020). Entrepreneurship Education Promotes Individual Entrepreneurial Intention: Does Proactive Personality Work? OALib, 07(10), 1-15. https://doi.org/10.4236/oalib.1106835

Tasia, F. E., \& Nurhasanah, E. (2019). Partisipasi Perempuan Dalam Pendidikan Tinggi Dan Pengaruh Pendidikan Tinggi Pada Perempuan: Sebuah Studi Literatur. Pekobis Jurnal Pendidikan, 4(1). https://doi.org/10.30537/sjcms.v4i1 